\author{
Barbara Strzałkowska \\ Cardinal Stefan Wyszyński University in Warsaw \\ ORCID: 0000-0002-6306-4322
}

\title{
The Book of Nahum and the Book of Jonah: Debate Within the Twelve Prophets?'
}

\begin{abstract}
Since antiquity, the issue of the inconsistency between the Book of Nahum and the Book of Jonah has been addressed, one regarding both its content and its message. At various times, it was settled in different ways. The current state of biblical research seems to allow us to put forth a daring thesis that both Books have more in common than merely Nineveh as the subject matter, which they approach from a different angle. There seem to be grounds to see these two Books as vestiges of an intracanonical debate waged within the Book of the Twelve.
\end{abstract}

Keywords: Book of Nahum, Book of Jonah, Book of the Twelve, canonical approach

Since antiquity, the specific tension between the content and the theological message of the Books of Jonah and Nahum has been discerned. As only few other in the Hebrew Bible, both end in a question mark. Both tackle a similar subject, the destruction of Nineveh, but their attitudes towards it are extremely polarised: one emphasises the divine retribution, the other-God's mercy on the city. For that reason, it has been speculated whether within the book of the Twelve Prophets, that they both are a part of, there may

\footnotetext{
${ }^{1}$ This article is a translation of the article originally published in Polish: Barbara Strzałkowska, "Księga Nahuma i Księga Jonasza: debata wewnątrz zbioru Dwunastu Proroków?," Collectanea Theologica 81 (2011) no. 4: 29-46. Translated from Polish by Lingua Lab.
} 
have been an intracanonical debate. ${ }^{2}$ Conversely, there were other attempts at settling that issue. The tension between the Book of Jonah and the Book of Nahum was already noted in ancient commentaries on both Books.

\section{Ancient Sources}

Due to the fact that in antiquity both Books were considered to convey the historical truth, it was impossible not to notice the inconsistency between them, regarding the faith of Nineveh. On the one hand, in the Book of Nahum we are furnished with an account of the destruction of the city, alongside an interpretation thereof pointing to the undoing of oppressors. On the other, in the Book of Jonah we come across a description of the city's repentance (characteristically, contrary to the wishes of the Lord's prophet), after which God grants His mercy to the city.

This contradiction seemed all the more evident when both Books came to be dated. The Jewish tradition saw the Book of Jonah as predating the Book of Nahum (which identified Jonah with a prophet of the same name, active during the reign of Jeroboam II, in the eighth century B.C., mentioned in $2 \mathrm{Kgs} 14: 25) .{ }^{3}$ Such a dating

\footnotetext{
${ }^{2}$ In spite of the seemingly obvious status of the issue, not many works have dealt with the comparison of Nahum and Jonah; albeit, as noted by D.L. Petersen: "these two Books should be read together, to enable one to discover the fullness of the prophetic commentary regarding the fate of Nineveh" (Idem, The Prophetic Literature. An Introduction, Louisville 2002, 199). In the number of works tackling the pair of Books one could include the following papers: C. Conroy, "Jonah and Nahum in the Book of the Twelve: Who Has the Last Word?" Proceedings of the Irish Biblical Association 32 (2009): 1-23; H.C.P. Kim, "Jonah Read Intertextually," Journal of Biblical Literature 126, no. 3(2007): 497-528 (on Jonah and Nahum in particular, see 507-12; on the relation between Jonah and the Book of the Twelve, see 516-27, and 512-16 on Jonah and Joel); F.T. Glasson, "The Final Question - In Nahum and Jonah," Expository Times 81 (1970): 54-5. There is also a commentary that discusses both Books in a single volume: A.S. Van Der Woude, Jona - Nahum, De Prediking van het Oude Testament, Nijkern 1978. ${ }^{3}$ In the latter passage, there is a mention of the Lord's "servant" (עֶבֶ) — "Jonah son

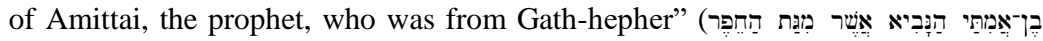
יניז $)$. On the potential connection of the figure of Jonah son of Amittai with the Book of Jonah, see for instance: H. GESE, "Jona Ben Amittai und das Jonabuch," in: Idem, Alttestamentliche Studien, Tübingen 1991, 122-38 (esp. 126-7).
} 
entailed a theological problem: why would the prophet Nahum (active in the seventh century B.C., more often then not associated with the reign of king Manasseh) ${ }^{4}$ have pronounced the verdict against the city and presented its destruction, considering that Nineveh had converted and made penance already during the times of Jonah? There were several ways in which the Jewish tradition tackled theses inconsistencies. ${ }^{5}$

First of all, attempts were made at diminishing or entirely disregarding the role of the repentance of the inhabitants of Nineveh (and of God's mercy towards them).

The first of the sources which make us pay attention to this topic, albeit perhaps unintentionally, is the deuterocanonical Book of Tobit. ${ }^{6}$ According to the most widespread opinion, it was created ca. 200 B.C., and its Greek text was preserved in two versions - the longer $\left(\mathrm{G}^{\mathrm{II}}\right)$ and the shorter one $\left(\mathrm{G}^{\mathrm{I}}\right)$-however, the former is considered to be older and follow the original more closely. ${ }^{7}$ In Tob 14:3-4 (following $\mathrm{G}^{\mathrm{II}}$ ), there appears the motif of the prophecies regarding Nineveh, when Tobit on his deathbed calls for his son (also Tobit), and warns him, saying:

4 Thus, it was presented for instance by Seder 'Olam Rabba 20; cf. B. Ego, "The Repentance of Niniveh in the Story of Jonah and Nahum's Prophecy of the City's Destruction: Aggadic Solutions for an Exegetical Problem in the Book of the Twelve," in: Society of Biblical Literature 2000 Seminar Papers: One Hundred Thirty-Sixth Annual Meeting: November 17-21, 2000: Opryland Hotel: Nashville, Tennessee, SBL 2000 Seminar Papers Series 39, Atlanta (Ga.) 2000, 243 (f.n. 5).

${ }^{5}$ On that, see B. EGO, "The Repentance of Niniveh," 243-53; see also an abridged version of the same paper: Eadem, "The Repentance of Nineveh in the Story of Jonah and Nahum's Prophecy of the City's Destruction - A Coherent Reading of the Book of the Twelve as Reflected in the Aggada," in: Thematic Threads in the Book of the Twelve, P.L. Redditt, A. SCHART, eds., Beihefte zur Zeitschrift für die alttestamentliche Wissenschaft 325, Berlin-New York 2003, 155-64.

${ }^{6}$ B. EGO, "The Repentance of Niniveh," $243 \mathrm{ff}$.

${ }^{7}$ On that issue in the context considered, see B. Ego, Buch Tobit: Unterweisung in erzählender Form, Jüdische Schriften aus hellenistisch-römischer Zeit 2/6, Gütersloh 1999, 875ff. (on the texts and the corr. literature), and 899ff. (on the dating with the corr. literature); cf. Eadem, "The Repentance of Niniveh," 243ff. In the Polish literature on the dating and the complexity of the texts in the Book of Tobit, see: M. Wojciechowski, Księga Tobiasza, czyli Tobita. Opowieść o miłości rodzinnej. Wstęp - przekład z oryginatu - komentarz, Nowy Komentarz Biblijny. Stary Testament 12, Częstochowa 2005, 17-19 (on the text), and 20-5 (on the history of its origin). 


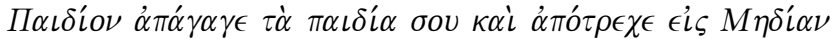

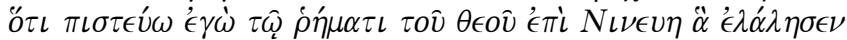

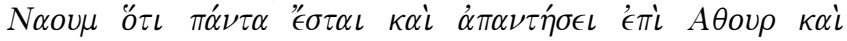

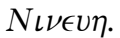

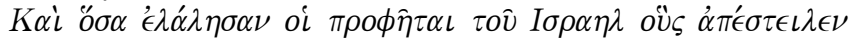

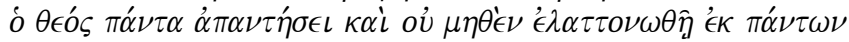
$\tau \hat{\omega} \nu \dot{\rho} \eta \mu \alpha \dot{\alpha} \tau \omega \nu$.

"My son, take your children and hurry off to Media, for I believe the word of God that Nahum spoke about Nineveh, that all these things will take place and overtake Assyria and Nineveh.

Indeed, everything that was spoken by the prophets of Israel, whom God sent, will occur. None of all their words will fail, but all will come true at their appointed times."

In the same passage in the later and shorter version $\mathrm{G}^{\mathrm{I}}$, we can read that Tobit instructs his son Tobias to escape to Media, for Nineveh would befall what had been said about it by the prophet

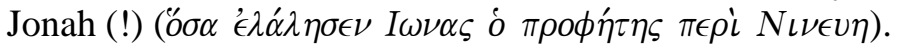

It seems very unlikely that the copyist mixed the names of Nahum and Jonah unwittingly, especially because in v. 14:8 in $G^{I}$ (but not in $\mathrm{G}^{\mathrm{II}}$ ) there is a further reference to Jonah's prophecy of the destruction of Nineveh. ${ }^{9}$ Many commentators of the Book of Tobit have pointed out that such a replacement of the prophet's name in the shorter text must have been erroneous, or at least "inaccurate," 10 for "the message of Nahum against Nineveh was very explicit, whereas in the Book of Jonah Nineveh was able to avoid destruction due to their penance (Jonah 3:14)." course of events seems to be that the author of the shorter text of Tobit $\left(\mathrm{G}^{\mathrm{I}}\right)$, by equating the message of Nahum with that of Jonah (by leaving out the motif of the repentance of the inhabitants of Nineveh, so markedly and vividly presented in the Book of Jonah!),

\footnotetext{
${ }^{8}$ Cf. also the translation to Polish: Ibid., 178-9. (Trans. note: New Revised Standard Version of the Bible is used throughout the English version of the paper.)

${ }^{9}$ With regard to that, see: B. Ego, "The Repentance of Niniveh," 244-5.

${ }^{10}$ Cf. M. Wojciechowski, "Księga Tobiasza,” 141 (f.n. d).

11 Ibid.
} 
neither committed an error nor an inaccuracy, but deliberately aligned his version with the manner of interpreting the Book of Jonah, perhaps popular in his times, and that made it possible to render the books identical with regard to Nineveh. Thus, already at the stage of the Holy Scripture taking shape, the issue of the tension between the content and the theological message of both Books was removed or mitigated.

In a very similar manner, by omitting the conversion of the inhabitants of Nineveh and God's mercy, the story of Jonah and Nineveh was reported by Josephus in his Jewish Antiquities (9:213-214), where, having presented the story of Jonah and the sea monster, he wrote (9:214):

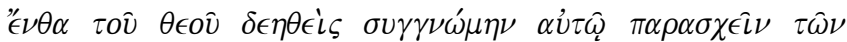

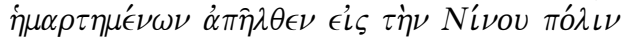

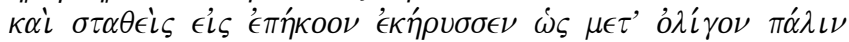

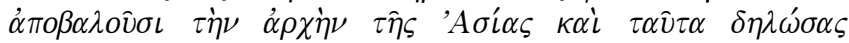 $\dot{\nu} \pi \epsilon \sigma \tau \rho \epsilon \psi \epsilon \delta \iota \epsilon \xi \bar{\eta} \lambda \theta o \nu$

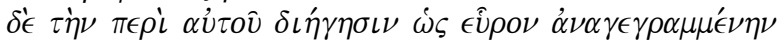

\begin{abstract}
"And there, on his prayer to God, he obtained pardon for his sins, and went to the city Nineveh,

where he stood so as to be heard, and preached, that in a very little time they should lose the dominion of Asia. And when he had published this, he returned.

Now I have given this account about him as I found it written [in our books]." 12
\end{abstract}

The extent to which Josephus altered Jonah's history is rather striking, as it even pertains to minor motifs: according to the biblical Book, Jonah "began to go into the city, going a day's walk. And he

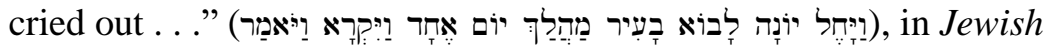
Antiquities, we read: "he stood so as to be heard, and preached" ( $\kappa \alpha$ ' $\sigma \tau \alpha \theta \epsilon i \varsigma \epsilon i \varsigma$ ' $\epsilon \pi \dot{\eta} \kappa o o \nu$ 'є $\kappa \dot{\eta} \rho v \sigma \sigma \epsilon \nu)$. Furthermore, the Book of Jonah underscores the size of the city- "an exceedingly large city, a three

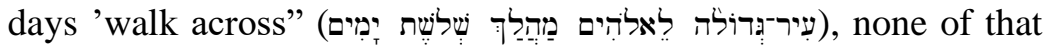
made its way to Josephus.

${ }^{12}$ Antiquities of the Jews, ed. and trans. W. Whiston, Peabody (Mass.) 1987. 
However, Josephus also changes one of the crucial elements of the content: according to him, having completed his heralding,

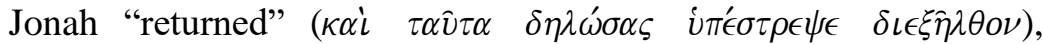
whereas from the Book of Jonah we know that after the instance of preaching, there were significant theological results to the history of Jonah: the repentance of the inhabitants of Nineveh, the prophet's dissatisfaction at that development, and ultimately God's mercy. None of these motifs was preserved by Josephus, who additionally concludes his narrative of Jonah by remarking that he gave an

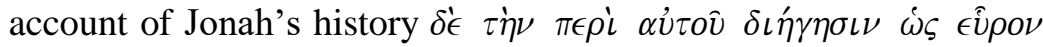
$\dot{\alpha} \nu \alpha \gamma \epsilon \gamma \rho \alpha \mu \mu \mu^{\prime} \nu \eta \nu$ ("as he found it written [in the books]"). This selfexculpatory phrase of sorts by the ancient author, alongside the reference to some unspecified "books," may rather indicate his concealment of what constituted the theologically inconvenient motif of that story, known from the actually recorded Book of Jonah, which in all likelihood he may have even been familiar with.

In that way, the problem of inconsistencies between Nah and Jonah was removed, resulting in the books being equated.

Following E. Bickerman, B. Ego has pointed out that such levelling of these two Books with regard to anything that pertained to the history of Nineveh may also have served another purposethe apology of Jonah as an authentic and not false prophet. ${ }^{13}$ For if his prophecies of mercy offered to the city had not come true, while the heralding of the fall expressed by Nahum had, it could mean that Jonah had not really been a true prophet of the Lord. Perhaps it was for that reason that, at the stage of antique considerations of both Books, both prophecies came to be treated as fulfilled, i.e., as foreseeing the fall of Nineveh. The thesis seems to be corroborated by a passage later in Jewish Antiquities by Josephus (9:242), where he provides an account of the prophecies by Nahum, underscoring that "all which thing happened about Nineveh a hundred and fifteen years afterward." 14

${ }^{13}$ Cf. B. Ego, "The Repentance of Niniveh," 246 f.; see also E. Bickerman, Four Strange Books of the Bible. Jonah / Daniel / Kohelet / Ester, New York 1967, 33-8. ${ }^{14}$ Antiquities of the Jews, ed. and trans. W. Whiston, Peabody (Mass.) 1987. Cf. B. Ego, "The Repentance of Niniveh," 247. 
Secondly, a different way to solve the problem of the contradiction between the two Books was put forth in the Targumic tradition, where it was decided that the repentance by the inhabitants of Nineveh must have been short-lived. For that reason, when they ultimately reverted to their misbehaviour, the time came for the prophet Nahum to deliver his message and the verdict against the city. Thus they were able to explain away what they considered to be merely an apparent tension between the two Books.

For instance, the Targum Pseudo-Jonathan to Nahum ${ }^{15}$ presented the case in the said manner, explaining at the outset (1:1):

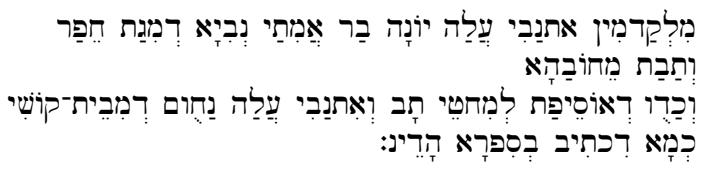

„First Jonah son of Amittai, the prophet from z Gath-Hepher, spoke [against Nineveh], and it turned away from its sins, but later when it returned to its transgressions, it was Nahum from Bet Koshi who spoke against her [Nineveh], as recorded in this book."

This is also the path that some of the subsequent Jewish commentaries will follow, for instance that by Rashi on the Book of Nahum, ${ }^{16}$ as well as some rabbinic traditions. ${ }^{17}$

Although the oldest mention of the repentance of the inhabitants of Nineveh in the Mishnah specifies that the penance made by them may be treated as an exemplary instance of repentance, not only for pagan nations, but even for the very Israelites ${ }^{18}$ (the $\mathrm{Ta}$ 'anit tractate

\footnotetext{
${ }^{15}$ Cf. ibid., 249.

${ }^{16}$ Cf. ibid.
}

${ }^{17}$ For details, reg. the Book of Nahum, see: Trei Asar II. Twelve Prophets II. Micah, Nahum, Habakkuk, Zephaniah, Haggai, Zechariah, Malachi. A New Translation with a Commentary Anthologized from Talmudic and Rabbinic Sources, ed. Y. Stavsky, ArtScroll Tanach Series, New York 1988; reg. the Book of Jonah, see: Sefer Jonah. Jonah. A New Translation with a Commentary Anthologized from Talmudic and Rabbinic Sources, ed. M. Zlotowitz, ArtScroll Tanach Series, New York 1988.

${ }^{18}$ B. Ego, "The Repentance of Niniveh," 247. 
from the Moed order 2:1 ${ }^{19}$ ), it concurrently points out that the repentance of the inhabitants of Nineveh had not been longlived.

Some of the rabbinic commentaries regarding that opinion proved even more detailed. The Midrash Pirke de-Rabbi Eliezer, subsequently repeated in the medieval commentaries, went on to specify that the inhabitants of Nineveh reverted to committing transgressions only four decades after having repented, ${ }^{20}$ thus already in the following generation, and their misdeeds grew even more severe than those of their predecessors. Such line of reasoning leaves us with the conclusion that Nahum performed his prophetic duty soon after Jonah, less than the usually accepted period of a hundred years. Rabbis aware of the issue - such as, for instance, A.D. David Luria - indicated with precision that Nineveh suffered destruction twice, with the prophecy of Nahum pertaining to the latter of those events. ${ }^{21}$ Meanwhile, the Targum on the Book of Jonah, commenting on v. 4:5, would add, in turn, that having preached, Jonah "sat down, to observe the ultimate fate of the city"22 - as if expecting the repentance of the inhabitants of Nineveh to be temporary.

It does not alter the fact that by adding the above details, these commentaries attempted to conceal the existing discrepancy between the message of the pair of Books.

The third method of settling the issue consisted in a kind of reconciliation between both texts, by way of assuming that the repentance by Nineveh had not been genuine. Thus, not only was it short-live, but also merely apparent. Such an opinion can be found in a part of the Jerusalem Talmud, based on the already mentioned Ta 'anit tractate from the Moed order 2:1. Rabbi Shimon ben Lakish is believed to have claimed that the repentance of the inhabitants of Nineveh had been deceitful, "they did return whatever they held in their hands, but they did not return the things concealed in their

${ }^{19}$ Cf. The Babylonian Talmud. Translated into English with Notes, Glossary and Indices, ed. I. Epstein, London 1935-1952, ad loc.

${ }^{20}$ B. Ego, "The Repentance of Niniveh," 249.

${ }^{21}$ Ibid., 250.

${ }^{22}$ Cf. J.M. Sasson, Jonah, Anchor Bible Commentaries 24b, New York 1990, 289; cf. also: C. Conroy, "Jonah and Nahum," 1 (f.n. 3). 
chests, coffers, and drawers." ${ }^{23}$ Rabbis underscored that the penance made by Nineveh had been feigned, that it was an act of hypocrisy, a trick of sorts, intended to lull God to sleep. That is why Nahum had proclaimed the destruction of the city once again, and God had to bring it to pass.

These were the methods used to deal with the texts of both Books, with the concurrent explanation of the issues that emerged from any such interpretations.

Christian commentaries from the period made less frequent attempts at addressing the problem. Church Fathers did not devote as much attention to the tension between the two Books, as the Jewish tradition did in its multifaceted undertakings. It has to be said, however, that the Christian solutions to the problem emerging from the pair of Books, would generally go in two main directions. On the one hand, much like the Jewish ones, they would present the repentance of the inhabitants of Nineveh as short-lived, hence the need of a repeated intervention by Nahum, and on the other-they would underscore an element missing from the Jewish literature, namely the obstinacy of the chosen people, as instantiated by Jonah. ${ }^{24}$

Among those professing the former notion was Theodoret of Cyrus in his commentary on the Book of Nahum 1:3. ${ }^{25} \mathrm{He}$ settles the issue in an exactly the same manner as the Targum Pseudo-Jonathan, by showing that the repentance of the inhabitants of Nineveh had only been temporary. Similar was the attitude of Jerome in is commentary to the Book of Jonah. ${ }^{26}$

On the other hand, against the backdrop of the exemplary penance performed by Nineveh, Church Fathers showed the lack thereof on the part of the Jewish prophet, as the symbol of the

\footnotetext{
${ }^{23}$ B. Ego, "The Repentance of Niniveh," 250, as cited in: J. Neusner, The Talmud of the Land of Israel. A Preliminary Translation and Explanation, vol. 18: Besah and Taanit, Chicago Studies in the History of Judaism, Chicago 1987, 180-1.

${ }^{24}$ For more on that, see E. Biser, "Zur frühchristlischenVerständnis des Buches Jonas," Bibel und Kirche 17 (1962): 19-21; Y.-M. Duval, Le livre de Jonas dans la littérature chrétienne grecque et latine. Sources et influence du Commentaire sur Jonas de saint Jérôme, Sources Augustiennes, Paris 1973.

${ }^{25}$ PG 81,1789-1792; cf. C. Conroy, "Jonah and Nahum," 2 (f.n. 4).

${ }^{26}$ PL 25,1119; cf. C. Conroy, "Jonah and Nahum," 2 (f.n. 4).
} 
obstinacy of the entire nation of Israel. ${ }^{27}$ Clement of Rome, for instance, set Nineveh as a good role model for penance (in his First Epistle 3:4-6:4, and 7:7). ${ }^{28}$ As it often occurred, such an attitude assumed by early Christian writers was intended as polemical against the Jewish community. A similarly polemical stance can be detected in the rabbinic writings. Some claim that the rabbinic charge against the inhabitants of Nineveh for their dishonesty in repentance, and their underscoring of there not being a contradiction in the message of the Books of Jonah and Nahum, was clearly polemical against the Christian interpretation, which entailed an accusation of Jonah himself. ${ }^{29}$ Nevertheless, even Jewish authors had a lot to blame Jonah for, even in the Book of Jonah alone. Hence, as emphasised by E. Bickerman, what had emerged in Jewish thought, was only re-appropriated by Church Fathers against the Jewish authors of the idea. ${ }^{30}$

All the ancient methods of addressing the tension between the two Books can be boiled down to the issues of their dating, and their historical interpretation. All the ancient traditions discussed (both the Jewish and the Christian ones) showed the Book of Nahum as having been created later than the Book of Jonah, and that in turn gave rise to the questions of the theological significance of the message of both books. Currently, there is a different approach to the historicity of the pair, their dating has changed; however, the issue of their theological content and their contradictory message has not been removed.

\section{Contemporary Approach to the Issue of Jonah-Nahum}

Among the most widespread contemporary tendencies in the research on the Books of the so-called minor prophets, is the one that returns to their reading developed already in the antiquity, that

${ }^{27}$ B. Ego, "The Repentance of Niniveh," 251.

${ }^{28}$ Ibid., 252 (f.n. 30).

${ }^{29}$ Ibid., 251; cf. also E. Urbach, "The Repentance of the People of Nineveh and the Discussions Between Jews and Christians," Tarbiz 20 (1949): 118-22.

${ }^{30}$ E. Bickerman, "Les deux erreurs du prophète Jonas," in: Idem, Studies in Jewish and Christian History. Part One, Leiden 1976, 33-71; cf. also: B. Ego, "The Repentance of Niniveh," 252. 
is, treating the entire Book of the Twelve as a single whole. ${ }^{31}$ So the collection was treated by the Jewish traditions (one could indicate here the findings of the scrolls of the Twelve throughout the Judaean Desert, as well as the writings by Josephus, for instance Against Apion 1:38-42; Talmud in the Bava Batra tractate 14b-15a), ${ }^{32}$ as well as the Christian ones (texts by early-Christian writers, such as: Cyril of Jerusalem among the Greek Fathers, and Cyprian, Jerome, and Augustine, ${ }^{33}$ among the Latin Fathers). ${ }^{34}$ Even in the very Old Testament some see the corroboration of such an attitude, in the deuterocanonical Wisdom of Sirach 49:10 ("May the bones of the Twelve Prophets ${ }^{35}-\delta \omega \delta \epsilon \kappa \alpha \quad \pi \rho \circ \phi \eta \tau \hat{\omega} \nu$ - send forth new life from where they lie, for they comforted the people of Jacob and delivered them with confident hope"). ${ }^{36}$

31 Much has been written on this subject, see esp. J. Nogalski, Redactional Processes in the Book of the Twelve, Beihefte zur Zeitschrift für die alttestamentliche Wissenschaft (BZAW) 218, Berlin, New York 1993; Reading and Hearing the Book of the Twelve, ed. Idem, SBL Symposium Series 15, Atlanta (Ga.) 2000. In the latter, cf. the article: A. Schart, "Reconstructing the Redaction History of the Twelve Prophets: Problems and Models," 34-48; see also a more extensive work: Idem, Die Entstehung des Zwölfprophetenbuchs: Neubearbeitungen von Amos im Rahmen schriftenübergreifender Redaktionsprozesse, Beihefte zur Zeitschrift für die alttestamentliche Wissenschaft (BZAW) 260, Berlin 1998. Other works on the subject, see for instance D.R. Slavitt, The Book of the Twelve Prophets, London 2000. Recently, the text of the entire Book of the Twelve has been elaborated in the most precise thus far edition of the Hebrew Bible: The Twelve Minor Prophets = עשר תרי, ed. A. Gelston, Biblia Hebraica Quinta editione cum apparatu critico novis curis elaborato 13, Stuttgart 2010.

32 The above sources as cited in: C. Conroy, "Jonah and Nahum," 2.

${ }^{33}$ Since Augustine (De civitate Dei 18,29), the Catholic Church adopted the name prophetae minores "the Minor Prophets"; Augustine referred to that collection in such a way, because these books were simply shorter than the "major" prophets (Isaiah, Ezekiel, Jeremiah, and-in the Christian tradition following LXXDaniel).

34 The above sources as cited in: C. Conroy, "Jonah and Nahum," 2 (f.n. 5). For a more extensive treatment of the subject, see A. Ferreiro, The Twelve Prophets, Ancient Christian Commentary on Scripture. Old Testament 14, Downers Grove 2003.

35 According to some scholars - in a capitalised form: the Twelve Prophets, precisely as the name of the collection; cf. C. Conroy, "Jonah and Nahum," 2.

36 This passage constitutes the most cited text corroborating the fact that in the Jewish diaspora in Alexandria, and potentially thoroughly the Jewish world of the Hellenistic period, the Twelve Prophets were taken as a whole, as a collection. 
Such an attitude assumed throughout antiquity, of course, did not result in the respective books of the collection never being treated individually; however, their proximity often made scholars interpret them together. Hence, the greater scrutiny that the relations between the books in the set were subject to, and the more accentuated the status of any discrepancies or contradictions in their texts-also in the case of the Books of Jonah and Nahum. ${ }^{37}$ That has not changed nowadays.

The current tendencies branch off into several directions, among which C. Conroy identified:

- synchronic reading (underscoring the unity of the Book of the Twelve, with an emphasis placed on the role of intertextuality, and content-wise interdependencies of the respective books in the set regarding the vocabulary, but also the message - here of importance can be, for instance, the sequence of books in the canon);

- diachronic reading (assuming a development and mutual influence of the individual texts in the Book of the Twelve, in terms both of their content and theology-here of importance can be which of the Books is considered to have been the first created, and which were written as determined by the already familiar texts). ${ }^{38}$

Obviously, in the case of the debate regarding the Books of Nahum and Jonah, both contemporary approaches have an important role to play. The former takes into consideration their position within the canon of the Book of the Twelve. Important factors within the latter approach include the dating of both Books, and their potential mutual influence, which - due to the discrepancy between themseems to further underscore the possible internal debate within the entire collection. Furthermore, not without significance is the fact

\footnotetext{
${ }^{37}$ Albeit these books can also be associated with others from the collection: the Book of Nahum often tends to be juxtaposed with the Book of Habakkuk, due to their dating, content, and size (cf. for instance: T. Lescow, "Die Komposition der Bücher Nahum und Habakuk," Biblische Notizen, 76 (1995): 59-85); meanwhile, the Book of Jonah is often related to the Book of Joel, as well as presented within the wider network of connections with the entire Book of the Twelve, naturally including the Book of Nahum (on that, cf. the extensive analysis: H.C.P. Kim, "Jonah Read Intertextually," Journal of Biblical Literature 126, no. 3 (2007): 497528).

${ }^{38}$ C. Conroy, "Jonah and Nahum," 3-4.
} 
that in spite of their belonging to one collection, these books do remain autonomous, their literary character differs, and therefore the identification of their genres will also prove valuable for their interpretation.

First of all, the position within the canon. Besides the aforementioned ancient interpretations, the connection between the Book of Nahum and the Book of Jonah was also recognised by those who defined the canon of the sacred scriptures, and ordered them in the respective collections. In one of the canons of LXX, the Books of Nah and Jonah were placed next to one another, something that the Hebrew text never did (as these were separated therein with the Book of Micah) ${ }^{39}$ hence the conclusion that they must have been considered jointly. Some even believe that this Greek canon is a testament to an earlier sequence of texts in the Book of the Twelve. Should that be true, the oldest sources had the Books of Jonah and Nahum in a sense assigned to one another, and that would constitute a suggestion to read them together. ${ }^{40}$

Secondly, a simultaneous glance at both these Books obliges us to focus on their literary character. Insofar as the Book of Nahum remains a typical prophetic oracle, similar to others in the Book of the Twelve, though perhaps even harsher content-wise, the Book of Jonah seems completely atypical within the collection, as it is not so much a prophecy, but a narrative of a prophet (and quite an extraordinary one at that). In the recent decades, there have been many proposals attempting to identify the literary genre of Jonah. ${ }^{41}$ The most popular of those referred to it as a midrash.

${ }^{39} \mathrm{Cf}$. more detailed treatment of the position of both Books in the canons: Ibid., 6 .

40 Ibid., 7.

${ }^{41}$ On the literary genre of Jonah, see for instance S.L. McKenzie, "The Genre of Jonah," in: Seeing Signals, Reading Signs, ed. M.A. O'Brien, London 2004, 159-71; M. Orth, "Genre in Jonah: the Effects of Parody in the Book of Jonah," in: The Bible in the Light of Cuneiform Literature, eds. W.W. Hallo, B.W. Jones, G.L. Mattingly, Lewiston 1990, 257-81; A. Lange, "The Genre of the Book of Jonah in Light of Paratextual Literature from the Qumran Library," in: Prophecy After the Prophets? The Contribution of the Dead Sea Scrolls to the Understanding of Biblical and Extra-biblical Prophecy, eds. K. De Troyer, A. Lange, LeuvenParis-Walpole 2009, 193-202; F. Colin, "The Book of Jonah as a Comic Novella," Scripture Bulletin 36, nos. 1-2 (2006): 64-73; A.T. Desmond, "Jonah and Genre," Tyndale Bulletin 36 (1985): 35-59. 
It would be indicated by the language of the Book, its narrative style. The Book seems to display a greater affinity to the sapiential rather than the prophetic books, and on such reading it could be treated as a text considering its own prophetic tradition, in its familiar aspects: the election of Israel, the vision of God, who was to be vindictive against the oppressors of His people. The book took an open stand against such a vision, ultimately presenting God's mercy as the prevailing element. This stance and that of the Book of Nahumclearly suggesting the tradition of God's vengeance — could not be more contrasted.

Thirdly, the current research has shed a new light on the dating of the pair of Books. Even though the said ancient traditions considered the Book of Jonah to have been older than the Book of Nahum, it seems historically more plausible that the exact opposite was the case. ${ }^{42}$ This allows for a different interpretation of both Books. It removes the issue debated in the ancient commentaries: why should Nahum present his message, considering Jonah had already admonished Nineveh, and the city, having heard him, repented? However, another question arises in its stead, being perhaps the crucial one in the contemporary research on these Books: why should the Book of Jonah, seen as the younger of the two, refer again to Nineveh, considering that the topic had already been addressed, in an extremely different manner, by the prophet Nahum?

The reaction to the above question in turn determines the mutual interpretation of these Books. What appears to be the best answer is that the Book of Jonah may have been a polemic against the message conveyed in the Book of Nahum. Also, regarding his theology and vision of God. ${ }^{43}$ It is plausible especially if we read the Book of Jonah not as historical, or a prophetic one, but as a sapiential midrash, far removed from historical plausibility, yet very closely related to the profound truth and the issue of the wisdom of their

\footnotetext{
${ }^{42}$ On the dating of Jonah, see G.M. Landes, "Linguistic Criteria and the Date of the Book of Jonah," in: Eretz Israel: archaeological, historical and geographical studies. Harry M. Orlinsky Volume, Jerusalem 1982, 147-70.

${ }^{43}$ On the vision of God in both these Books, see C. Conroy, "Jonah and Nahum," 7-13 (the Book of Jonah), and 13-20 (the Book of Nahum).
} 
people. Thus, we could make an attempt at recognising the Book of Jonah as a sort of a canonical response to the Book of Nahum and its spirit.

\section{The Book of Jonah as a Response to the Message of the Book of Nahum}

With such an understanding of the relationship between these two Books, one has to underscore that the response provided by the Book of Jonah to the Book of Nahum unfolds on several levels. Most distinctly, these books answer one another with regard to their content and theology. ${ }^{44}$ Both Nahum and Jonah tell the stories of prophets who foretell the destruction of Nineveh (and-in the case of Nahum - of this prophecy coming to pass). By showing the history of Nineveh, they present different visions of God, different views of the election of the people of Israel. These motifs will concurrently unify and separate the Books. Additionally, both Books (an infrequent and significant occurrence in the Old Testament) end in question marks.

The first of our prophets is Nahum. ${ }^{45}$ In its entirety, as already indicated, his Book constitutes a verdict against Nineveh (in line

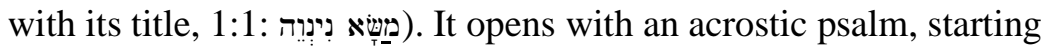

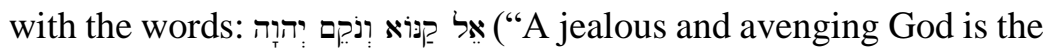
Lord"), whereas the main body of the Book comprises a narrative poem of the destruction of Nineveh: the announcement of the razing of the city, and Nahum's ironic grief over the fallen Nineveh. The Book appears to be presenting the image of the city's destruction, expressed in all likelihood in the context of its actual collapse. In the

\footnotetext{
${ }^{44}$ Both Books feature, for instance, similar designations for God (e.g., Nah 1:3, and Jonah 4:2); cf. C. Conroy, "Jonah and Nahum," 16-17. The current paper does not provide a detailed analysis thereof, as it is merely intended to indicate a certain perspective on these Books, which may entail more extensive research and reflection on their content and the common (or contradictory) motifs expressed in the Books.

${ }^{45}$ On the current state of research on this Book, see M. Weigl, "Current Research on the Book of Nahum: Exegetical Methodologies in Turmoil?" Currents in Research: Biblical Studies [1993-2001], no. 9 (2001): 81-130; cf. also D.L. Christensen, Nahum, Anchor Yale Bible 24f, New Heaven 2009, esp. 17-25.
} 
main section of the Book, the name of God appears only on three occasions $(2: 3.14 ; 3: 5)$; however, the account of the city's destruction is presented in its entirety as a consequence of God's command. ${ }^{46}$ Importantly, the Book does not provide any words of consolation, even though - and this is one of the greatest paradoxes of Nahum - the protagonist's name means precisely that, “consolation" (Hebr. נְחוּם).

With no words of solace provided in the Book, the question has been asked: where should we look for it? The most obvious answer seems to be that a pious Israelite would draw comfort from the misfortune of the enemy and tormentor of his people, from the fact that Lord his God had given his verdict, and judged fairly the nation (for Nineveh symbolises the entire Assyria) which oppressed Israel. The consolation lies in God having protected his people - after all without any merit on their part.

Our other main character is Jonah. ${ }^{48}$ Also a prophet, though slightly atypical — nevertheless obviously proud of being a member of God's chosen people (cf. Jonah 1:9) - he does whatever in his power not to follow the will of God. The Book of Jonah is a prophetic book, but with a twist. It is a tale, a midrash, some refer to it as a "satire" of sorts. ${ }^{49}$

The book opens as "prophetically" as it gets: what we come across first are the words of the prophetic formula (1:1-2: "Now the word of the Lord came to Jonah son of Amittai, saying: «Go at once to Nineveh, that great city, and cry out against it; for their wickedness has come up before me»"'). However, the prophet's answer, and his subsequent flight in the direction opposite to the one commanded by the Lord, will rather make one smile than feel the

${ }^{46}$ C. Conroy, "Jonah and Nahum," 14.

${ }^{47}$ On the paradoxical nature of the meanings of the names of both discussed prophets (Nahum and Jonah), see H.C.P. Kim, "Jonah Read Intertextually," 508.

${ }^{48}$ For current state of research on the book, see for instance C.M. Kenneth, "Jonah in Recent Research," Currents in Research: Biblical Studies [1993-2001], no. 7 (1999): 97-118.

${ }^{49}$ F. Colin, "The Book of Jonah as a Comic Novella," Scripture Bulletin 36, nos. 1-2 (2006): 64-73; M. Orth, "Genre in Jonah: the Effects of Parody in the Book of Jonah," in: The Bible in the Light of Cuneiform Literature, eds. W.W. Hallo, B.W. Jones, G.L. Mattingly, Lewiston 1990, 257-81. 
horror of the prophecy, as was the case in Micah, Zephaniah, Nahum, and others.

The prophet's name is Jonah (meaning "dove") - he is the only prophet shown making desperate attempts to avoid his calling, either failing to obey God's commands, or performing them in a completely counterproductive manner. Jonah is also the sole paradoxical prophet, who, having been forced to preach repentance to Nineveh, in spite of his lack of enthusiasm, will prove so efficient that the entire city will repent at his single call. And a further paradox consists in that he will not be satisfied with this turn of the events! The Book can be read in detail and scoured for at times downright comical motifs. However, there is more to it than just these minor amusements. Above all, prophet Jonah is proud of who he is, even though he does not fulfil the tasks required of his calling. All who surround him: the sailors, the sinful inhabitants of Nineveh, repent sooner than he does. ${ }^{50}$

At the core of the Book of Nahum was the heralding of the verdict against the corrupt Nineveh, and the account of its fulfilment. Jonah is supposed to herald a similar message - and he ultimately passes God's judgment: "Forty days more, and Nineveh shall be

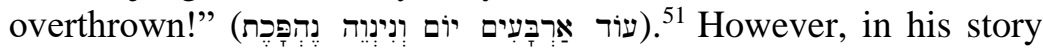
the inhabitants of Nineveh did repent, and radically so, with their king and even their cattle, and God showed them mercy, which left the Lord's prophet exasperated. However, the last word in the Book of Jonah belongs to God, and the word is mercy.

Thus, both books, Nahum and Jonah, deal with the same event; however, telling their story, they draw different conclusions, perceiving the events as if from two points of view: they present a different vision of God, a different vision of the election of the people, different fate of Nineveh.

\footnotetext{
${ }^{50}$ Hence, the subsequent early-Christian would underscore the prophet's obstinacy; however, as he is presented in such a caricatural manner, it seems likely that he was perceived that way also, and perhaps most of all, by Jews themselves.

${ }^{51} \mathrm{LXX}$ has the passage translated in a rather curious manner. Greek translator puts into Jonah's mouth even more radical words: "three more days and Nineveh shall

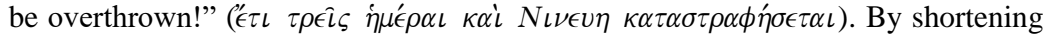
the time given to Nineveh to repent, the text gains even more dramatic tension.
} 
Now, in what way can the Book of Jonah constitute a response to the Book of Nahum?

Some scholars believe that the message of Nahum was complemented by the Book of Jonah on the theological level: for it turns out that even for Nineveh the road to salvation remains open if the sinners renounce their transgressions. It seems that we could venture even further-here, these sinners will be saved sooner than those whose attitude is distant from fulfilling God's will, regardless of whether they belong to the chosen people. What is subject to criticism through Jonah's stance is indeed the particularism of Israel, and hence in some sense the core of the Book of Nahum: the consolation stemming from the misfortune of the enemy, or rather from God's protection over His elected people. One could say that in the Book of Jonah such an attitude, seeing one's origins in the nation of Israel as a privilege-regardless of whether or not individual members of the nation called by God (as Jonas was) perform His will-is unreservedly mocked and presented as a caricature. However, the book's sense and message were perfectly well understood by those who read and pondered about it.

This response also pertains to the very vision of God, the element that most differentiates one book from the other: the vengeful (though just) God from the Book of Nahum is presented in the Book of Jonah as the merciful Lord of history. ${ }^{52}$ It can be observed already at the level of expressing the truth about God. In the Book of Nahum we encounter the phrase (1:2):

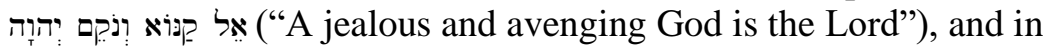
the Book of Johan the exact opposite; (4:2):

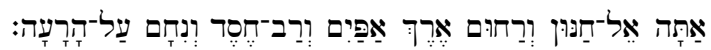

"You are a gracious God and merciful, slow to anger, and abounding in steadfast love, and ready to relent from punishing. ${ }^{, 53}$

52 C. Conroy, "Jonah and Nahum," 7.

53 The paradoxical status of these expressions in the context of the two Books was pointed out by H.C.P. Kim, Jonah Read Intertextually, 508-9. 
On such reading, Jonah as the later of the two books and one much more sapiential than prophetic in nature (a midrash of sorts) could constitute a response to the Book of Nahum. A response reinterpreting its own tradition and somewhat ridiculing Israel's national attitudes and vices, especially that of particularism. Even though some Israelites took Nahum's verdict against Nineveh as their consolation, Jonah demonstrates that the final word always belongs to God, and that word is not anger, but mercy.

During the considerations of these issue, the question was posed how the Book of Jonah could constitute a response to the Book of Nahum, in light of the fact that in all canons, including the Greek one, which brings the books next to one another, their order is reverse: first Jonah then Nahum - does the last word belong to Nahum, after all? $?^{54}$

C. Coneroy believes that the pair of Books was included in the canon in such a sequence, so that the reader, when reflecting on God's mercy as the ultimate answer, could not forget that in spite of all, God is "jealous" and just, as such was the fundamental message of the Torah. ${ }^{55}$ At the same time, he points out that a tool helpful in settling the issue may be a diachronic (and not merely synchronic) analysis of both Books. Most exegetes who use it to study the Book of the Twelve are left with no doubts as to the fact that the Book of Jonah was added to the collection much later than the Book of Nahum, ${ }^{56}$ and therefore according to those researches it is Jonah who has the last word.

In these debates, of no small importance seems to be the fact that both Books end in a question mark (the majority of scholars agree as to that). ${ }^{57}$ This question - that goes unanswered in both books is posed to the readers (listeners), everyone of whom has to find their own answer thereto.

Whereas in the Book of Nahum the final question in a sense leaves the reader in a state of hopelessness, or rather pensiveness

\footnotetext{
54 Ibid., 21.

55 Ibid.

56 Ibid., 21 (f.n. 55, incl. literature).

${ }^{57}$ On that issue, see T.F. Glasson, "The Final Question - In Nahum and Jonah," Expository Times 81 (1970): 54-5.
} 
about the fate of the wicked (Nah 3:19: "There is no assuaging your hurt, your wound is mortal. All who hear the news about you clap their hands over you. For who has ever escaped your endless cruelty?"), the Book of Jonah leaves the reader with a question, the answer to which lies in the unspoken hope in God's mercy (Jonah 4:10-11: "Then the Lord said, "You are concerned about the bush, for which you did not labor and which you did not grow; it came into being in a night and perished in a night. And should I not be concerned about Nineveh, that great city, in which there are more than a hundred and twenty thousand persons who do not know their right hand from their left, and also many animals?»").

The question concluding the Book of Jonah may constitute a response to the one at the end of the Book of Nahum. ${ }^{58}$ The important fact here is that whereas the question in the Book of Nahum was posed by man - the prophet Nahum, standing over the ruins of a city, the question in the Book of Jonah is posed by God, who directs history according to his own wishes. And His is the final word, which, however, always requires man's answer. And an appropriate attitude.

\section{Conclusion}

The reception of the Book of Nahum proves rather difficult for contemporary readers, the challenging elements being the vision of a vengeful God, and the attitude of the Israelites, who saw it as a source of comfort. Perhaps it was also challenging for the readers and listeners of the Hebrew Bible during the time period that it told about? Perhaps it was for that reason that they tried already at the stage of shaping the Holy Scripture to provide an answer to its difficult message. And that answer may have been the Book of Jonah, so very different from it. Since antiquity the issue of inconsistency between the Book of Nahum and the Book of Jonah has been addressed, one regarding both its content and its message. At various times, it was settled in different ways. The current state of biblical research seems to allow us to put forth a daring thesis that both Books have more in common than merely Nineveh as the

58 Ibid., 55. 
subject matter, which they approach from a different angle. There seem to be grounds to see these two Books as vestiges of an intracanonical debate waged within the Book of the Twelve. A debate demanding that one questions the meaning of their own tradition. And the question is rather sapiential than prophetic in its nature. The Book of Job and the Book of Ecclesiastes will later inquire in a similar vein. However, the Book of Jonah appears to be posing it, too. 